\title{
Arcuate Nucleus
}

National Cancer Institute

\section{Source}

National Cancer Institute. Arcuate Nucleus. NCI Thesaurus. Code C52711.

A nucleus located in the middle hypothalamus in the most ventral part of the third ventricle near the entrance of the infundibular recess. Its small cells are in close contact with the ependyma. 